\title{
CONVERSATIONS AND POSTCARDS
}

\section{Joan Yochim}

Many words and phrases Virginia Woolf used in "A Sketch of the Past," were those I had searched for to convey the importance of my childhood places. While reading Woolf's journal entires, I felt as if the phrases were mine, not hers. I absorbed the atmosphere and images she created and compared our summer memories. Her journal notations movitated me to write along with her. After a few pages in each journal, I realized that we were having a silent dialogue. We were discussing similarities of place features, activities, and feelings. I was drawn into her remembrances and invited her to share mine.

I was the more fortunate party in our conversation; Woolf always spoke first. She referred to the distance of her summer home from London where she spent winters: "The distance was a drawback; it meant we could only go to St. Ives in the summer. Yet that made the country more intense. . . nothing we had as children was so important to us as our summers in Cornwall (1976, p. 110)." The intensity of Woolf's feelings for her Cornwall experiences was due partly to the specialness of having a summer house and to the ritual of returning every summer. Her reflection clarified for me my own reasons for choosing our family beach house as a focus for understanding an earlier self and for using places as vehicles for personal description. I shared with Virginia, through my hand-written notebook, detailed accounts of yearly trips back and forth between city and shore. Country and shore times of childhood were unified and bounded, cut off from everydayness and more easily remembered. Images of those events and places remained visually intact and whole, unchanged and easier to interpret. As I copy these lines from my journal, with her diary sitting nearby, I wonder which one of us is speaking. I am drawn back to the text for an answer and become involved in other descriptions.

Woolf's manner of writing enhanced an impression of chats between two old friends. Her way of inventorying and stringing together pictur- 
esque phrases, punctuated by semicolons, and adding asides, separated by dashes, allowed me to interrupt with reflections and pictures of my own. She tried to convey what it was like to be a child in the country: "To get away to the end of England; to have our own house. . . to hear the waves breaking. .. to sail in the lugger... to dig in the sands. .. to scramble over rocks. .. to go down into town (1976, p. 110)." Is that Virginia or Joan I see now in memory scampering over sand dune and rock jetty and in early evenings walking into town for an ice cream cone covered with jimmies? Her litany guided me to notice extraordinary details of shore days.
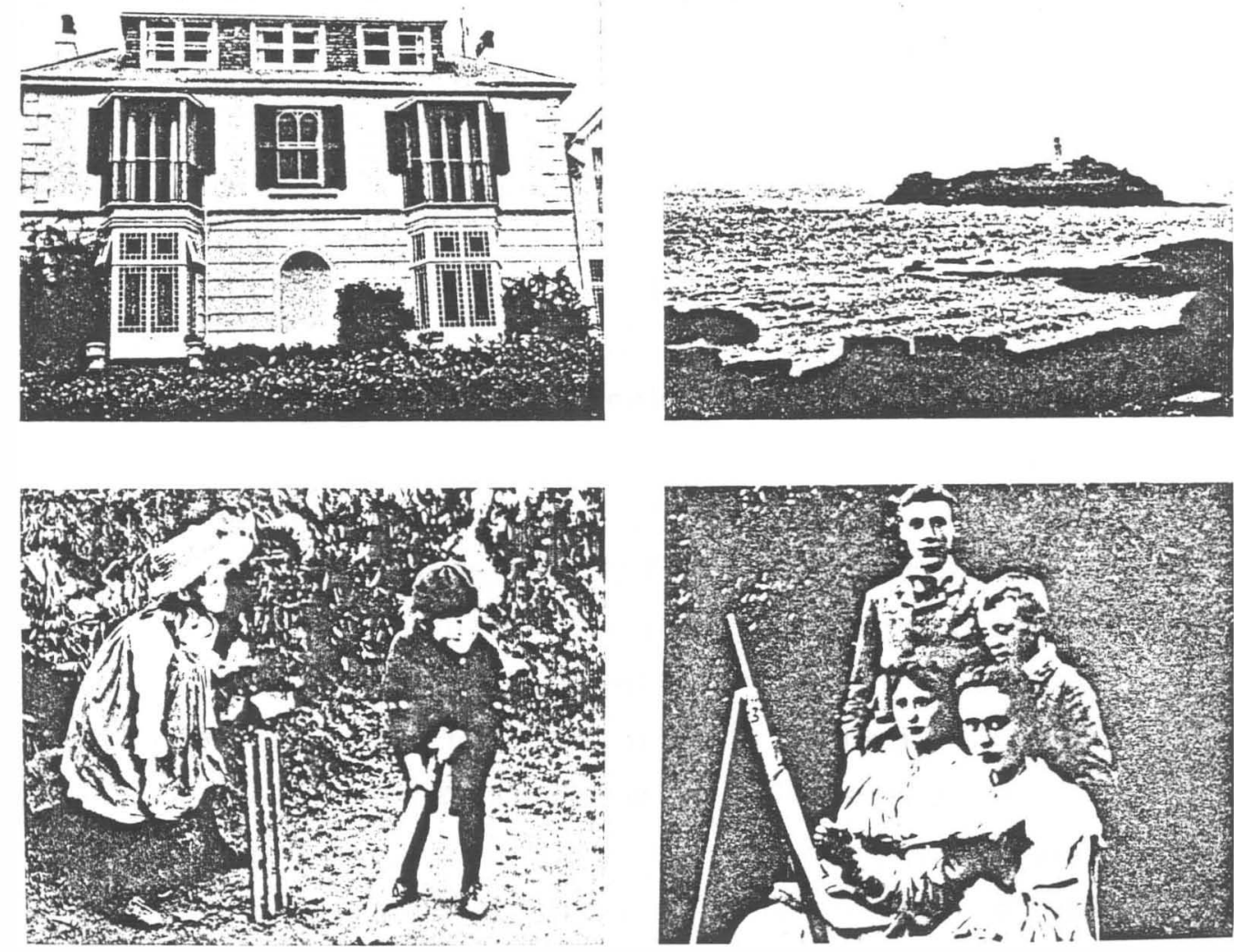

Her view from Lookout Place evoked in me a walk to the end of Norwood Avenue where I gazed over the dunes. As I stood with bare feet buried in warm sand, I looked to the right and left along thin strips of bleached sand, broken into small beaches by jumbled rock jetties; every summer we chall- 
enged ourselves and each other to add one more beach to the length of an afternoon walk. I felt the lulling motion of waves as I viewed and counted scattered heads bobbing in the ocean - swimmers protected from possible harm by attractive, muscular, young lifeguards sitting high above sand in white, box-like chairs; my eyes scanned the horizon, taking note that sky was almost indistinguishable from ocean in much the same way that long summer days gradually faded into night; the boats - some barely dots in the distance - reminded me of early morning fishing trips with the whole family crowded into our old garvey. Few of my city friends loved the beach and water as I did. The scratch of sand on sunburned legs. . . thick callouses on always-bare feet... the splash of a cold wave on warm skin ... these were irritations to city dwellers. I associated them, as I'm sure Virginia would have, with long, lazy, special summer days of sun and freedom. Each detail could motivate a story of its own. .. and all could be woven into a
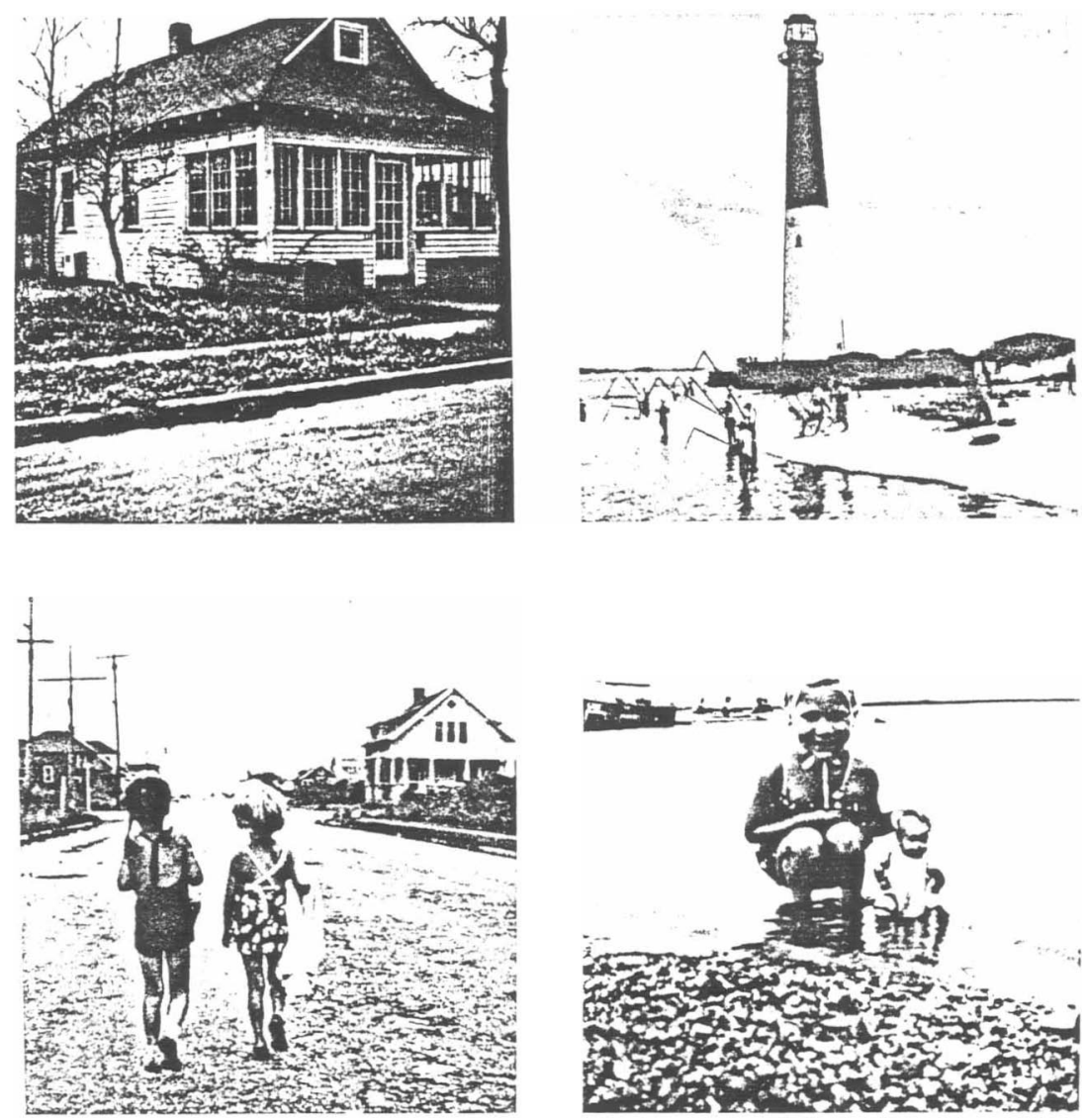
place portrait or the story of a little girl, privileged to live in a special time and place. Neither shore nor country stayed the same.

In much of her essay Woolf was concerned with how to weave individual scenes into coherent stories of whole lives. Images of "moments of being" were embedded into many more moments of non-being. .. of unconsciously lived everydayness. One journal entry explained that ". . I I think I have discovered a possible form for these notes. That is, to make them include the present - at least enough of the present to serve as a platform to stand on ... (1976, p. 75)." It seems natural that as a writer Woolf would use her adult self to relate separate early scenes and moments. Through carefully chosen and ordered phrases she moves us back and forth between past and present; in the process, she discovers and explains who she is and was, what her influences were and are, and how the adult writer uses past places as contexts for present ideas and feelings.

Without realizing it, we have been lead to know the writer, not the little girl, and how writing for her was an act of exploration. What was it like to live in England during those years? "Now for the first time I have written down [my moments of being], and I realize something I have never realized before. . . I felt I had made a discovery. . . perhaps this is the strongest pleasure known to me. It is the rapture I get when in writing I seem to be discovering what belongs to what... that behind the wool is hidden a pattern. . . that the whole world is a work of art (p. 71)." Sharing and finally understanding the depth of Virginia's feelings, I am left with a great need to make my own explorations and discoveries who were those individuals and what were those places that formed me and, now, represent half-a-lifetime? Will my discoveries about myself relieve the hollow ache emerging from long talks with Virginia?

To "see" my own places and myself, I took Virginia's advice and wrote. And as I wrote I began to make sense of my world. . . how my places came to have meaning and how those meanings influence interactions with the present. Although I wrote primarily of homes and familiy activites - like Woolf, to put the past to rest - some journal entries spoke of art making 
places. I wondered, for example, how my high school art classroom in an old stable and looking much like a real artist's studio - influenced my romantic notion of "being an artist". Or if my preference for sharing art making places and activities with others is grounded in activities shared with Nother - painting endless sea shells with brightly colored nail polish; cutting out pictures from magazines to fill innumberable "theme" scrapbooks; passing long summer evenings tediously following lines in paint-by-number oils of dogs, birds and beach scenes. Virginia, did you spend long afternoons and evenings making up and writing down stories? Did you have a desk of your own? Or did you share space at the dining room table, at Father's large desk; or spread your art making things out on the big double bed as I did?

Conversing with Woolf caused me to reevaluate art education research methods. Could I serve as an intermediary by sharing art place meanings communicated to me by high school art students? Could I write, rewrite, and find patterns of individual and group meanings hidden behind talk of everydayness in art classrooms.... of mixing paints, painting still lifes, hanging reproductions and learning about primary colors? How might 1 write to communicate the sense of students' dialogues with each other and with art teachers about the importance of the art room itself - its organization and objects? Would this format describe the influences of places called art rooms on future art appreciators and makers? Would conversationally relating my place meanings and student meanings help other art teachers create more meaningful environments?

Having discovered a format for investigating the significance of physical environments and a method for enhancing writing skills, I continued my journal keeping while reading other authors. My initial reaction to Joan Didion's essays, according to notebook entries dated Spring 1987, was one of excitement in finding a kindred soul, another woman who had, as an adult, lived through the chaotic 60 s. So many of her images and flash character studies restructured my remembered feelings and experiences of teaching in a large city high school.

While I read pages one Joan had written years earlier and more pages 
another Joan had just written in response, I gradually realized that the first Joan was not inviting me to share fondly remembered places and people, that my responses were not a communication with her at all. I skimmed the surface of her vividly worded, picturesque paragraphs and chose phrases which closely matched my memories, then allowed my imagination to carry on. I changed the tone of her essays by filling in with my own details and meanings as I told myself my own 60 s stories. Didion had provided an occasion to reminisce by sending glossy, brightly colored picture postcards picked up during travels made to find herself; she didn't want to discuss the places with me. Unlike Woolf who had invited me in for tea and talk, Didion remained a distant observer and mailed social puzzles and questions.

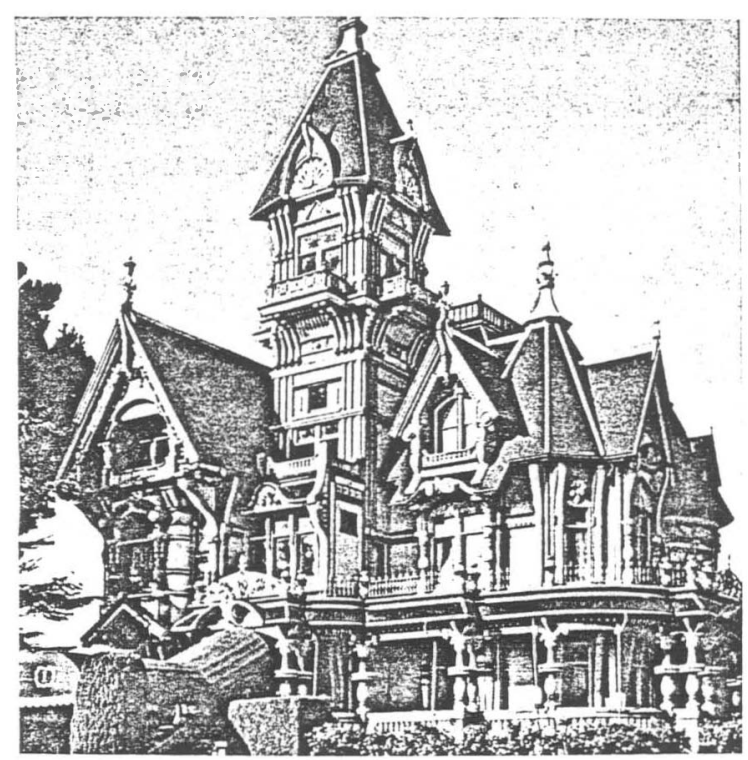

I became so enamored with flashy surfaces and personal reverie that I failed to read the hastily scrawled messages on postcard backs. The reverse sides revealed confusing, ironical descriptions and well-worn adages. On the back of a photograph of preserved Newport Mansions she wrote: "The places loom large along Bellevue Avenue... The silk curtains frayed but the gargoyles intact. . . I had been promised that the summer houses were museums and warned that they were monstrosities, had been assured that the way of life they suggested was graceful... a and that it was gross beyond 
belief... (p. 28)." P.S. Money can't buy happiness and pleasure; freedom is an illusion; progress for its own sake is an empty goal. Didion sent many postcards: one from old California, picturing Valley towns and rich fields - with a message about crowded Aerojet parking lots and mazes of multilaned highways; another picturing a crumbling, flower covered prison with a large No Tresspassing sign - the message, a sentimental statement about a prisoner's soap dish. Which, she wanted to know, was the "real" California, the "real" Alcatraz, and the "real" Newport? When, she inquired, had things changed so drastically? As Didion took me on trips across the country searching for places she had dreamed about but could not find, I revisited the shore. Where were the small cottages, the intimate, familiar beaches, the ice cream stand and crowded, dark grocery store? When had they been replaced with sprawling parking lots, schooners sitting on dry land serving as gift shops, concrete and glass motels, and modern, oddly shaped homes awkwardly raised on pilings? My shore had disappeared except in memory and old photographs.
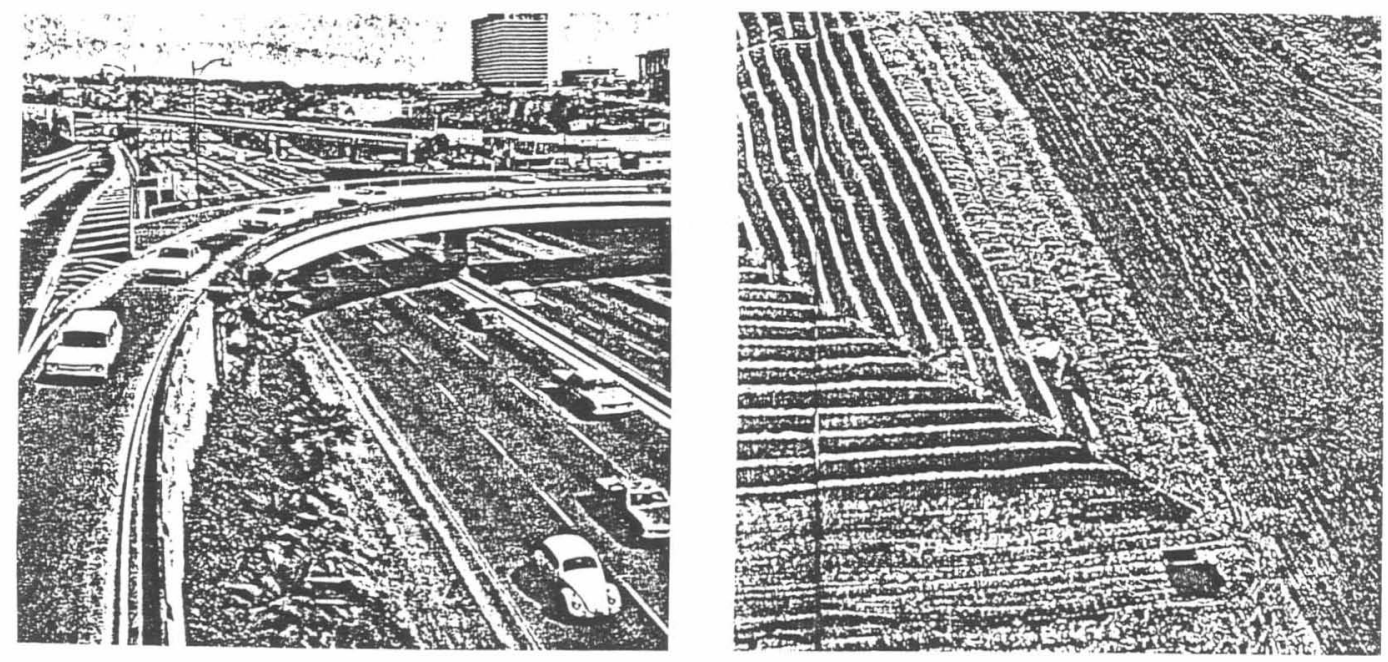

By using carefully observed, descriptive place details, Didion caused me to look beyond the shiny surfaces and reconsider the values with which I had been raised. Was 'reality' an illusion after all? We were raised, I wrote in my response journal, during the forties and fifties believing in 
stability and continuity. As all little girls and boys at that time, we knew that we would grow up to be carbon copies of our mothers and fathers. We would carry out their dreams. And we would follow their values and pass them on to those who came after us. National and neighborhood pride, family solidarity and loyalty, respect for leaders and elders, and adherence to dictates of authorities were rules we learned in family routines at home, were values we saw embedded in objects surrounding us. Behaving, listening to the code, meant listening to quietly told tales with a moral delivered by parent, teacher, scout leader or minister. Rules weren't broken without a price. The code, learned sitting around kitchen tables in always-used places and in assigned school desks, held until the Spring of 1971. I remember the afternoon when I looked around my classroom and realized that $I$ wasn't the teacher I had planned to be; that the art room in which I taught seemed different as did the students.

I took out albums of photographs to explore past places. Had my places and people changed as Didion's essays suggested? She sent me her travel snapshots from California. I looked at captioned photos of Haight Street hippies, Didion's children who hadn't thought much of the future and wanted only to triumph over life's "don'ts". Her hand-written comments revealed a confused adult being swept along - an adult who said nothing much, didn't ask why but went home to resolve confusion by writing. Didion's characters, high on drugs, lost, searching for excitement and meaning or "something", recalled relationships with my students.

I was standing in the doorway of my cluttered classroom when I heard the skates rattling over the square floor tiles of the hall around the corner. This was my signal to rush across the front of the room and open the store room door behind my teacher's desk. Just as I accomplished this a tall figure propelled by smooth skate wheels grabbed the door jamb and swung into the room full-speed-ahead toward the store room. The French teacher was running behind trying to catch up. He was yelling something about suspending students who skated inside the school building, wearing long gold chains with large medallions dragging on the floor. By the time this teacher came into sight, I was able to stand quite calmly behind my 
desk guarding the closet door. "No one skated into my room," I informed him when asked. He left immediately and quietly, knowing that unless he wanted to call me a liar he had been defeated once again. "Hoss" emerged with a large grin wearing street shoes and no chain. This was a little game we played often that spring. I recalled Joan's comment about a college campus: "The place simply never seemed serious (1979, p. 38)."

Karla was an art major in her senior year. She was a quiet young woman who was often hard to reach and read but who showed considerable artistic promise. I didn't really get to know her until she started to dog-sit for me with her friend Sally. I hadn't realized they were friends. Karla was so reticent, Sally so outgoing. Karla didn't seem the type of student to be involved with drugs. I saw no evidence of this in class as I did with Sally and many others: the far-away, glassy-eyed, dreamy look which was the answer to every question; the giddy, happy response to being taken to task for not working. But they were friends and Karla came around with Sally. Karla eventually became one of my apartment "regulars": those girls whose parents didn't "understand the new scene", whose parents were glad to have someone who tried to understand and who was willing to take responsibility for interpreting and controlling their children's behavior. I came to know Karla and her particular problems quickly. Her parents, divorced and remarried, were moving from the city. Karla would have to transfer schools six months before graduation. Without thinking about the responsibilities
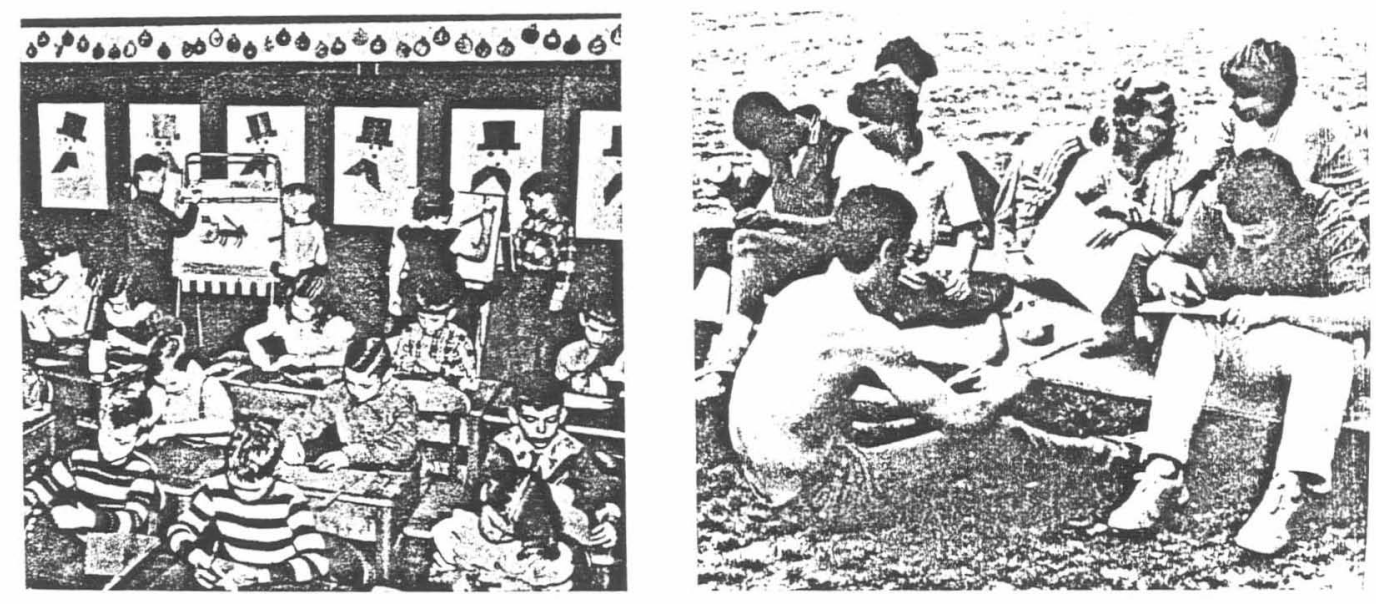

Working Papers in Art Education 1986 
or the consequences, 1 told her that the only answer for her was to move in with me. She did. Classroom and apartment merged, problems followed.

At first glance it would seem that the earlier purposes of schooling had vanished during the late $60 \mathrm{~s}$ and early $70 \mathrm{~s}$. The critics claim that we educators had gotten lazy: that we had stopped valuing and teaching basic skills and knowledge, that classroom order and self-discipline were things of the past. We were spoiling the children and young people. My classroom "games" and material disorder did little to dispute their claims. I can't disagree with the results of education during those years; I'm still not sure what the changes were or how they came about. I will disagree, however, with the personal attack on the teachers. We also were the victims of a new society. We bought into the "new", the "relevant", the "meaningful" along with our students and society at large. Now I'm not sure we understood what we were doing. The code had changed and we didn't know the rules or outcomes.

What do reading journals and essays and keeping personal notebooks have to do with art education research? "We tell ourselves stories in order to live (Didion, 1979, p. 11)." I suggest that we tell ourselves stories in order to know where we've been, to find ourselves and give ourselves identity and meaning. As Woolf pointed out, we explore and search for patterns and explanations. The excerpts recounted suggest that research concerns and questions might be discovered in autobiographical writings; that stories of particular places might serve as a focus for research or to unify research questions; that analysis of interactions with self and others in particular places might provide research answers; that research may be a personal adventure. Understanding past places reveals that meanings, social and personal, are derived from the interaction of people, physical environments, and activities. The uses that writers make of features of physical environments to convey personal questions or meanings indicate that they are more significant than might be assumed in day-to-day living By concentrating on physical environments of art learning, how they are planned, used, and interpreted by art teachers and students, we might reshape art meanings we communicate to students and have other stories 
to tell later. We might understand changes we create and tell better stories. Finally, new approaches to description and interpretation emerge through reading, writing, and sharing place stories. Literary formats and foci humanize research, make it alive and meaningful for readers, and provide concrete illustrations of concepts and theories so often abstract and seemingly insignificant to daily existence.

\section{REFERENCES}

Didion, Joan. Slouching toward Bethlehem. N.Y.: Simon \& Schuster, 1981. Didion, Joan. The white album. N.Y.: Simon $\varepsilon$ Schuster, 1979.

Schulkind, Jeanne (ed.). Virginia Woolf: moments of being. N.Y.: Harcourt, Brace, Jovanovich, 1976. 